\title{
Texto como discurso: a formação do leitor crítico
}

Maria Aparecida Lino Pauliukonis ${ }^{\star}$

\section{Resumo}

Considerando-se que um texto é resultante de uma operação linguístico-discursiva, que está fundamentado em um "contrato" social e em um projeto de influência do emissor sobre o receptor, discute-se como as novas perspectivas da linguística do texto e da análise do discurso podem contribuir para um ensino mais crítico e produtivo de leitura e de produção textual.

Palavras-chave: Discurso. Interação. Texto.

\section{Introdução}

Talvez um dos grandes problemas relacionados ao ensino de texto seja a falta de clareza na definição dos conteúdos e métodos utilizados nos estudos de interpretação: o aluno concebe uma ideia vaga de que a interpretação é intuitiva e, sendo assim, vale tudo que puder associar, ou, então, que ele deveria submeter-se a uma interpretação que é fruto da experiência do professor, um leitor mais experiente e capaz de resolver os intrincados problemas de sentido.

Tradicionalmente, o ensino de leitura e de produção textual tem enfrentado dificuldades de várias ordens: em primeiro lugar porque não apresenta conteúdo programático definido como o que existe para a gramática da frase, por exemplo, no campo da fonologia, da morfologia e

\footnotetext{
Docente Associada IV do Programa de Pós-Graduação de Letras Vernáculas da UFRJ; Docente Adjunta III do Programa de Pós-Graduação de Letras Vernáculas da UFRJ.
} 
da sintaxe; em segundo, pelo reduzido espaço que lhe é dedicado pelos professores sobrecarregados pelos extensos programas de descrição metalinguística e reconhecimento dos elementos da frase. Em razão disso, sobra pouco tempo para aulas de leitura, interpretação e produção textual. Muitas vezes, também, as aulas de interpretação resumem-se a discussões periféricas sobre o conteúdo das proposições, ou o texto é usado como pretexto para exercícios fragmentados de aplicação e de reconhecimento de conteúdo gramatical. Em suma, a escola continua a ensinar seus alunos a escrever e a analisar frases e períodos e a cobrar-lhes a confecção de textos coesos e coerentes. $O$ resultado não poderia ser mesmo produtivo.

À luz dessas questões, é possível pensar em uma revisão dos conteúdos tratados na gramática da frase, tendo em vista um ensino cuja meta seja uma visão discursivo-interativa da linguagem?

\section{A tradição e o ensino de texto}

É grande a perplexidade de educadores, pais e alunos diante do fracasso de nossos estudantes em avaliações feitas em escalas mundiais em que logramos, ainda, uma classificação medíocre, nos testes que medem a proficiência em leitura e produção de texto e, também, em ciências matemáticas. Se o assunto crise do ensino é antigo, muito se tem falado atualmente sobre soluções, e uma vasta bibliografia nos tem dado mostras da preocupação de linguistas, gramáticos e de toda a sociedade com seus cidadãos, que, embora considerados alfabetizados, são analfabetos funcionais em vários níveis.

Conscientes de que a temática é extremamente complexa e escapa a uma solução simplista, apresentaremos, neste espaço, reflexões e propostas alternativas para o problema, mediante o exame de duas questões: como se processa atualmente o ensino tradicional de texto e a validade de uma proposta fundamentada no apoio teórico da linguística do texto e da análise do discurso.

Toda técnica didática deriva de um conjunto de regras, crenças e atitudes em relação a seu objeto de estudo. No caso do ensino de línguas maternas, a exigência do tradicional rigor normativo baseia-se na crença de que, acima das variantes linguísticas usuais, há uma norma ideal, cuja dominação implica poder e distinção em uma sociedade que aceita diferenças sociais, mas prestigia o poder de uma elite dominante. O raciocínio contrário seria, segundo esse modelo, o caos de uma não exigência de padrão, um aceite incondicional das variantes que encontrariam respaldo nas diversas situações de uso da língua. Existe um meio-termo que pode situar melhor a questão, e isso muito se deve aos novos conhecimentos acerca da compreensão da interatividade que existe em todo fenômeno linguístico e que trazem novos parâmetros para o entendimento do que seria considerar 
toda manifestação de texto como realização de um discurso.

Tradicionalmente, o ensino de línguas apoia-se na prescrição de regras de realização da norma de prestígio. Acredita-se que, pela transmissão de modelos de "bom" uso e de uma metalinguagem, tradutora de um sistema homogêneo, poder-se-ia obter a contraparte de um desempenho eficiente dos alunos.

Comprova a prática, porém, que o ensino, por meio da descrição metalinguística de uma modalidade linguística, não contribui sozinho para a eficiência dos usuários. Discute-se, assim, a forma como os conteúdos são transmitidos em livros didáticos que privilegiam a descrição dos fenômenos, com ênfase na nomenclatura, em detrimento da compreensão da funcionalidade dos fenômenos linguísticos, e as implicações de todas as interações reais. Para citar alguns casos, no ensino de língua portuguesa, ainda impera a memorização de listas de prefixos e sufixos de origem grega e latina e de regras incoerentes para o emprego do hífen, a simples memorização de paradigmas de conjugações de verbos irregulares, de conjuntos de coletivos de uso duvidoso e as realizações de aumentativos, diminutivos e de plurais analógicos, sem respaldo no uso. Além disso, prevalece uma prática de enfoque fragmentado em tópicos de morfologia e de sintaxe, como classes de palavras e funções sintáticas com um fim em si mesmas. Todos esses itens do programa são fornecidos ao aluno por meio de uma prática que enfatiza exceções ou simples exercícios de memorização cuja única justificativa é a cobrança em provas de alguns concursos e vestibulares que testam o reconhecimento, e não o uso. Tudo isso dá ao aprendiz a sensação de que a língua portuguesa é difícil e só está acessível a uns poucos privilegiados, talvez o próprio professor de português.

À medida que exames e concursos começaram, já há algum tempo, a exigir, também, respostas discursivas não padronizadas, ou melhores testes de interpretação de textos e redação, em que se impõe a exigência de competências linguísticas, em níveis textuais e pragmáticos, confirmou-se a fragilidade dessa antiga prática pedagógica, refletida nos baixos desempenhos dos alunos na compreensão e na produção textual. Esse fato ainda é agravado pelo grande desinteresse dos jovens pela aquisição de uma base cultural que tem sua fonte na leitura de livros, jornais e revistas especializados, os quais competem com outras mídias, como a televisão e a internet, cujos textos apresentam-se mais generalizantes ou de base hipertextual.

Caberia, agora, outra reflexão sobre como tem sido a posição da escola diante dos avanços e das conquistas de novas pesquisas sobre teorias do texto e do discurso, aquisição da linguagem e cognição. A realidade não demonstra grandes mudanças: não se fez a transferência para o ensino das constatações a que chegaram as pesquisas em diversas áreas, e, muitas vezes, em sala de 
aula, ensina-se nova metalinguagem e discute-se muito sobre essas recentes teorias linguísticas que, muitas vezes, substituem uma tradição, a qual, bem direcionada, costuma resultar eficiente. Assim, são transmitidas aos alunos noções vagas e errôneas, camufladas por nomenclaturas inovadoras, tidas como salvação para o ensino. Essa falta de visão crítica do problema contribui para agravar a situação do ensino de português.

Sabemos que as novas concepções sobre o fenômeno linguageiro revelam-se fundamentais como embasamento ao professor, que pode fornecer ao educando uma visão mais abrangente sobre as potencialidades do fato linguístico e sua adequação a cada instância de comunicação, pois os atos de linguagem possuem repertório próprio e regras de coerções contratuais necessárias para serem eficazes. Deve ficar evidente que não estamos questionando todo o conteúdo do ensino, e muito menos o enfoque necessário na modalidade culta pela escola. Uma revisão crítica, todavia, sobre crenças e atitudes que existem em relação à linguagem, torna-se importante, dadas as condições em que se processa, ainda, $o$ ensino de gramática e texto atualmente.

Vale ressaltar outro valor: a ampliação da escolaridade a todas as classes sociais, que se verificou a partir da década de 1960, permitiu o acesso à escola de uma clientela diversificada de alunos, dotada de repertório linguístico bastante heterogêneo. As salas de aula não são mais constituídas de alunos pertencentes a uma classe social que domina um padrão de uso compatível com o que a sociedade dela espera, e sim por alunos de diferentes e variados registros linguísticos.

Em contrapartida, também não se justifica pensar que se pode adotar um falso liberalismo que prive esses novos alunos da obtenção de uma norma de prestígio ou da língua de poder (GNERRE, 1974); alijá-los, pois, da modalidade culta é impedir-lhes de participar das decisões de uma sociedade letrada e de base cultural, mas dominadora e que tem na linguagem uma forma a mais de repressão e um símbolo da manutenção de status e domínio político e social. Nunca é demais repetir a máxima sobre o ensino de gramática proposta por Evanildo Bechara (1987), para quem a grande e difícil missão do professor de português é transformar seu aluno em um "poliglota em sua própria língua", possibilitando-lhe meios de posicionar-se e escolher a língua funcional adequada a cada situação de uso, dando-lhe condições de se apropriar, também, da modalidade linguística de prestígio social.

Pelo exposto, não cogitamos, aqui, discutir o conteúdo das disciplinas, ou a simples substituição de uma forma didática por outra, ou de teorias tradicionais por teorias mais prestigiadas, mas avaliar uma nova compreensão do que seja o fenômeno da linguagem como um todo, o que perpassa a discussão primordial do que seja sua expressão principal: o 
texto visto como discurso. Nesse caso, como consequência, em vez de focalizar $o$ que ensinar na escola, fato relativo a problemas de conteúdo textual, talvez se devesse ficar na forma, no como ensinar e no objetivo, ou no para que ensinar, processos que deixam de ser circunstanciais para se tornar cruciais, quando se trata de problemas de aprendizagem e metodologias de ensino.

\section{Uma visão discursiva de texto}

Como já dissemos, certa corrente tradicional em educação tem concebido a aprendizagem linguística como o resultado da transmissão de uma única modalidade de linguagem culta, escrita ou oral, reflexo de um código fechado e homogêneo que o aluno deveria dominar independentemente de qualquer saber linguístico anterior aprendido intuitivamente pelo uso. Da passagem dessa prática educacional que privilegia a transmissão de conteúdos de um código de regras normativas fechado e homogêneo para uma alternativa que busca compreender a língua como um instrumento de comunicação interativa e de reconstrução da realidade, há muita diferença. Não se trata, portanto, apenas da ênfase na temática de variação. $O$ sistema linguístico deixa de ser considerado apenas fonte de transmissão de informações sobre o mundo real para operar como um mecanismo de recriação desse real e de uma forma atuante do sujeito emissor sobre o sujeito receptor e vice-versa. Diante disso, impõem-se outro conceito de gramática e de texto e, por seu turno, uma nova postura pedagógica para o ensino de leitura, interpretação e produção textuais.

Segundo concepções recentes das teorias linguísticas e discursivas que abordam a semântica da enunciação, ou a semântica do discurso, a língua somente existe na interlocução, pois, por meio do uso, é possível deduzir o sistema de regras que norteia e possibilita o jogo interativo. Dessa forma, as regras gerais do discurso não estão, a priori, disponíveis no sistema, mas são coconstruídas e detectadas durante o processo de comunicação, realizado sempre por intermédio de textos com base argumentativa, numa situação interacional bem definida e com regras próprias.

Essa noção de texto como discurso ou como uma unidade pertinente a um jogo dialógico e de atuação sociocomunicativa - objeto de estudo de uma versão mais recente da linguística do texto e da análise do discurso - caracteriza-se por possuir uma orientação temática cumpridora de uma função social. Está-se adotando aqui a noção de texto no nível do discurso, como um conjunto de enunciados "em função", ou seja, a ocorrência da textualidade realiza-se sob o ponto de vista sociointeracional. Portanto, somente quando o emissor realiza intencionalmente uma função textual, reconhecida pelo parceiro envolvido no processo de comunicação, o conjunto de enunciados 
linguísticos passa a se constituir como um texto coerente, de acordo, portanto, com a situação comunicativa.

Considerada a relevância da noção de texto como unidade de comunicação, intencional e interativa (CHARAUDEAU, 2008), impõe-se uma nova proposta pedagógica, fundada em uma nova metodologia de ensino de língua como discurso. No lugar de um estudo centrado na descrição dos elementos do sistema, isto é, na operação de reconhecimento e classificação dos termos envolvidos na constituição de frases, propõe-se um trabalho produtivo de interpretação e produção de enunciados, que permite ver os textos como a unidade superior da língua, da qual todos os outros elementos são partes constituintes; assim, morfemas, palavras e sintagmas, frases e períodos devem ser analisados a partir do texto produzido e limitado por restrições de acordo com um contrato social e enunciativo dos interagentes.

Essa nova metodologia prevê mudanças de enfoque na análise das partes constituintes dos textos. Nesse sentido, toda frase deve ser considerada como pertencente a um texto realizável em uma dada situação; dentro dessa perspectiva, somente é possível o reconhecimento de termos, por exemplo, concomitantemente à análise de sua inserção no conjunto de todos os enunciados do texto. Pode-se objetar que esse procedimento diz respeito à análise do cotexto ou do contexto e que isso já se faz tradicionalmente, mas a proposta de análise que aqui se apresen- ta vai um pouco mais além da análise do contexto tomado em seu sentido restrito, como veremos a seguir.

De acordo com os conceitos de uma semântica discursiva argumentativa, não há textos inocentes, pois todos partilham de uma intencionalidade, cuja descodificação advém do reconhecimento de vários fatores determinantes: o contexto extralinguístico, o contrato comunicativo que impera entre os parceiros, suas identidades sociais, as marcas linguísticas, "intencionais" ou não, deixadas pelo autor no texto, além da noção fundamental de gênero textual e modos de organização de discurso. Essa visão do texto como o resultado de um processo de coconstrução interativa e intencional entre um emissor e um real ou virtual receptor, que se processa sempre por meio da tessitura de elementos linguísticos e não linguísticos, não é usual nos nossos manuais didáticos e tampouco nas práticas interpretativas que focalizam os elementos constitutivos da gramática.

Por seu turno, os textos, muitas vezes, configuram-se como pretexto para aplicação das regras da gramática da frase e os exercícios de interpretação de textos literários ou não literários, que poderiam propiciar treinamento na descodificação da estrutura textual e dos princípios da intertextualidade, bem como abordam questões gerais e periféricas sobre o tema proposto, o papel dos personagens ou a divisão formal em parágrafos etc. Paradoxalmente, cobram-se dos alunos práticas efetivas de interpretação e de 
produção textual, e não causa espanto a professor algum o medo provocado em muitos alunos por uma prova sobre interpretação, ou o mal-estar diante de uma página em branco com a exigência de redação de textos argumentativos coesos e coerentes.

Se construir um texto é, segundo os conceitos das teorias discursivas, operar argumentativamente, podemos acrescentar que interpretá-lo é reconhecer, desmontar essa operação e produzir outra, processo do qual sempre decorre uma unidade textual diferente. Dessa forma, descodificar um texto é captar-lhe um dos sentidos possíveis para o qual os operadores ou as marcas argumentativas conduzem o raciocínio do leitor.

Torna-se oportuno relembrar aqui a etimologia do verbo "ler", do latim "legere", que, traz entre os seus sentidos possíveis, o de "roubar, captar" sentidos. Assim, o ato de ler define-se como captar sentidos ou selecionar, na medida em que determina um dentre outros muitos possíveis. Trata-se a leitura de uma operação de ordem subjetiva, mas também de uma técnica e realização de um delicado "jogo" que a escola deve ensinar sistematicamente a seus alunos, preparando-os para a aquisição de uma leitura mais crítica e consciente dos vários gêneros, o que depende do reconhecimento das várias operações e estratégias que constroem o texto e possibilitam processos de ler e interpretar. No lugar das tradicionais perguntas "o que isso quer dizer?", ou "o que o autor quis dizer?", são pertinentes outras indagações: "por que se diz de um determinado modo?" e "quais as consequências de sentido desse outro modo de dizer?".

Acrescentemos a essas considerações a afirmativa do filósofo Bakhtin (1970) de que todo texto é um mosaico de citações, isto é, todo texto constrói-se por referência a outros tantos que são evocados de muitas formas, linguística e situacionalmente. Pelo reconhecimento da intertextualidade e da interdiscursividade, o leitor aprende a ouvir as vozes de outros textos que ecoam e podem ser captadas no espaço de "manobras" da construção textual, que variam conforme o gênero textual e os modos de organização discursiva; quer dizer, formalmente, um texto narrativo diferencia-se de um texto argumentativo ou descritivo, também, pelo modo de encadeamento de elementos linguístico-discursivos.

Em que essa abordagem globalizante do ato comunicativo, a que se têm dedicado a linguística do texto e a análise do discurso , em suas várias fases - $\mathrm{e}$ mais recentemente, influenciadas pelos avanços da teoria da cognição -, diferencia-se de outras propostas de leitura que também se consideraram uma revolução no ensino? As teorias do texto e do discurso têm por objeto de estudo o texto como unidade de significação, fruto de uma competência comunicativa do emissor e do receptor que estão engajados em um processo de construção de sentido. Pretendem ir além de teorias anteriores, que tratam do texto como 
um produto e buscam reconsiderá-lo como um processo de coconstrução de sentido. Representam, dessa forma, uma evolução e alinham-se a uma tendência geral das ciências modernas na busca de uma forma mais abrangente e integradora de aquisição do conhecimento. Atualmente, Física e Química juntam-se quando o interesse é o estudo da estrutura do átomo; a Biomatemática aplica a tecnologia dos computadores na busca de soluções para problemas ambientais, e a Ecologia, cuja preocupação não se restringe apenas a fenômenos da natureza, estende sua atenção a problemas sócio-político-econômicos. Podemos dizer, desse modo, que a Ecologia está para as ciências experimentais como as teorias do texto estão para as ciências humanas, ou, como bem definiu Bernardez, "A Linguística do Texto é de certo modo uma ecologia da Linguística" (1982, p. 238), e, nesse sentido, é interdisciplinar e procura ver o fenômeno "texto" de forma abrangente e relacional.

Devemos ressaltar, portanto, o caráter integrador dessa abordagem: estuda o texto e suas relações com os vários fatores condicionantes, históricos, sociais, linguísticos, psicológicos e pragmáticos. Retoma aspectos da gramática tradicional, como o estudo do vocábulo, seus morfemas de gênero e de número, os verbos e as noções de tempo, aspecto e modo, os conectivos e os aspectos coesivos etc., mas os analisa segundo um prisma textual e sociocomunicativo. Procura fugir ao reducionismo a que outras correntes estavam sujeitas, sem desvincular-se totalmente dos modelos teóricos anteriores, legados pelo estruturalismo e, também, pelo gerativismo. Busca, por conseguinte, definir um rigor metodológico, sem o que cairia num trabalho impressionista com o texto, como o que foi praticado por um certo idealismo linguístico, que resistiu durante muito tempo.

A linguística do texto e a análise do discurso não constituem, ainda hoje, uma disciplina ou uma teoria única, mas se servem de um conjunto de modelos teóricos com um objetivo comum: explicitar todos os fenômenos que ocorrem no texto, integrando dados linguísticos, morfossintáticos, semânticos e dados extralinguísticos ou pragmáticos. Por serem interdisciplinares, enfrentam, ainda, questões difíceis relativas a seu objeto de estudo, definição de metodologia, identidade e autonomia.

Ressente-se, ainda hoje, da falta de difusão de material didático referente à análise da função discursiva dos componentes, ou de elementos significativos de um texto que levem o aluno a perceber todo o complexo processo de sua construção, responsável em grande parte por seu sentido. Pelas propostas tradicionais, analisa-se o conteúdo, o que o texto significa, e não o modo ou o porquê de tal significado; o aluno está acostumado a ver o texto como um produto pronto e acabado, portador de um sentido hegemônico, no qual ele não tem interferência como um sujeito pensante e criativo. 
A nova postura, em relação à análise de textos, apregoa que o aprendiz pode passar de leitor a coautor do texto, na medida em que interpretar é, também, reconstruir um novo texto, por meio de uma operação interativa com o autor e com o mundo, momento em que ele se torna um coautor (CARNEIRO, 2001).

Embora tenha se tornado um dos mais promissores campos de pesquisa na Europa, nos Estados Unidos, no Canadá e no Brasil, essa visão discursiva da língua, que já ocupa lugar de destaque em universidades e em congressos especializados, ainda não foi transmitida pedagogicamente, de forma eficaz, para o aprendizado de línguas. As mudanças, todavia, estão vindo devagar, mas se impondo de forma intensa e duradoura. Pesquisadores de várias universidades e de laboratórios de pesquisa, como os do CIAD-Rio ${ }^{1}$, por exemplo, estão empenhados em um projeto coletivo de pesquisa intitulado "Operações discursivas e construção do ethos dos enunciadores e sua interface com o ensino", numa proposta que envolve professores e alunos de graduação e pós-graduação das principais universidades cariocas: UFRJ, UFF, UERJ, dos Departamentos de Letras Vernáculas, de Linguística e Letras Neolatinas . O Grupo do CIAD-Rio tem divulgado a operacionalização didática de teorias propostas pela linguística do texto e pela análise do discurso, por meio de cursos para professores e alunos da graduação e da pós-graduação com resultados bastante promissores. Tam- bém, a participação constante de seus pesquisadores em congressos especializados e a publicação de livros e artigos permitem divulgar os resultados de suas investigações (2006, 2007, 2008).

Essas disciplinas configuram-se, hoje, como importantes campos de pesquisa, sobretudo por suas características interdisciplinares, propondo uma nova dinâmica de investigação dos elementos constitutivos de um texto e sua funcionalidade. Urge, portanto, que um maior número de pesquisadores de outras linhas de pesquisa, juntamente com professores dos diversos graus de ensino, una-se no sentido de se ampliar uma metodologia voltada para o ensino de texto como discurso. Esses esforços poderão contribuir para resolver ou minimizar problemas concernentes à leitura, à interpretação e à produção textual.

\section{A formação do leitor crítico}

Esse novo enfoque de texto visto como discurso, conforme enunciado aqui, implica considerar a importância da compreensão do sentido global e dos mecanismos produtores de sentido. Dessa forma, o texto como um todo significativo estrutura-se de forma que a junção das partes torna-se importante para a depreensão do todo, mas este se torna maior do que a soma de todas elas. Com base nisso, o estudo de texto poderia se fixar no exame cuidadoso dos mecanismos de estruturação de sentido; ou seja, seria necessário evidenciar, antes de 
tudo, o processo interacional entre um enunciador e um leitor, o qual se torna, também, o coenunciador do texto. Em vez de simplesmente se fixar o conteúdo das proposições - ou o que o texto/as palavras diz/dizem - talvez melhor seja enfatizar os processos de construção de sentido, analisar como o texto diz algo e, ao dizer, que efeitos de sentido consegue transmitir e, ainda, o mais importante: de que meios linguísticos e operações discursivas se vale a construção textual como um todo.

Um dos compromissos mais importantes da escola é tornar o aluno um leitor autônomo e um produtor independente de textos. Apesar de tantas sugestões pedagógicas e das pesquisas em discurso, os resultados têm sido pouco animadores, pois ainda não se oferecem subsídios para a prática efetiva de redação ou de leitura e interpretação textuais.

A escola não pode iludir-se com a ideia de que a interpretação ou a produção textual seja um dom que depende, principalmente, da sensibilidade do aluno. Ao contrário, essa é uma prática que, com um método sistemático, tem de ser apresentada pela escola para ser, paulatinamente, apreendida pelo aluno. Essa passagem do ensino tradicional, que tem como base a gramática da frase, para uma gramática de texto como discurso é um grande desafio que exige novas visões e metodologias.

Gramática de texto e de discurso, na acepção usada aqui, implica conhecimento do texto, ou, melhor, reconhe- cimento da função dos elementos que o compõem, e, do ponto de vista discursivo, o texto torna-se o mediador do processo de comunicação, o que requer um leitor/ produtor consciente e participativo desse processo. Nesse sentido, o ensino de gramática será muito mais eficaz quando privilegiar a reflexão sobre a língua em funcionamento em textos, e não apenas focar sua descrição ou realização em esquemas com vistas à aprendizagem da normatividade.

\section{Conclusão}

O tema enfocado procurou abranger o que a análise discursiva do texto denomina de "problematização do sentido de um texto", que consiste em compreender e analisar o "significado textual" em função da identidade dos contratantes do ato comunicativo, isto é, a partir da influência e da ação do sujeito emissor sobre o sujeito receptor, respeitando-se o conjunto de restrições linguísticas e discursivas. O significado, por sua vez, deriva de um contrato de comunicação que existe entre o emissor e o receptor e de um projeto de fala do emissor, que é aceito e reconhecido pelo receptor.

Procuramos levar em consideração não somente as operações linguísticas fundamentais que constituem os sentidos advindos da língua, cujo reconhecimento serve de base para a compreensão, mas também os processos discursivos que permitem reconstruir os subentendidos ou implícitos de qualquer texto, sentidos 
que permitem uma leitura mais produtiva. Defendemos, ainda, que, na interpretação textual, é preciso identificar o quadro contratual e a situação discursiva que vão consubstanciar a identidade dos participantes e a finalidade do ato discursivo. Essas operações constituem a base necessária para um processo mais consciente de interpretação e de produção de textos, orais ou escritos.

\section{Text as speech: the formation of critical reader}

\section{Abstract}

Considering that a text is the result of a linguistic-discursive operation, which is based on a "contract" and social influence in a project of the issuer on the receiver, discusses how the new erspectives of Linguistics and Text Analysis Discourse can contribute to a more critical and productive teaching of reading and of writing.

Keywords: Discourse. Interaction. Text.

\section{Nota}

1 Grupo CIAD-Rio (UFRJ, UFF, UERJ e UFRRJ) - Sede na UFRJ, Faculdade de Letras, Bloco H, $3^{\circ}$ Andar, Sala 310 (www.letras.ufrj.br/projetociad).

\section{Referências}

BAKHTIN, Mikhail. La poétique de Dostoievski. Paris: Seuil, 1970.

BECHARA, Evanildo. Ensino de gramática: opressão ou liberdade? São Paulo: Ática, 1999.

BERNARDEZ, Enrique. Introducción a la linguística del texto. Madrid: Espasa Calpe, 1982.

Teoria y epistemologia del texto. Madrid: Cathedra, 1995.

CARNEIRO, Agostinho Dias. Redação em construção. 2. ed. São Paulo: Moderna, 2001.

CHARAUDEAU, Patrick. Uma análise semiolinguística do discurso. In: DUCROT, Oswald. Dizer e não dizer. princípios de uma semântica linguística. São Paulo: Cultrix, 1998.

PAULIUKONIS, Maria Aparecida Lino. Alternativas para a solução da crise da leitura à luz da gramática textual. A crise da leitura, Rio de Janeiro: Faculdade de Letras, UFRJ, p. 148-155, 1993.

PAULIUKONIS, Maria Aparecida Lino et al. Estratégias de leitura: texto e ensino. Rio de Janeiro: Lucerna, 2006.

PAULIUKONIS, Maria Aparecida Lino; GAVAZZI, Sigrid (Orgs.) Da língua ao discurso: reflexões sobre o ensino. 2. ed. Rio de Janeiro: Lucerna/Nova Fronteira, 2007. p. 5-35.

PAULIUKONIS, Maria Aparecida Lino; LÚCIA, Ida (Orgs.). Linguagem e discurso: modos de organização. Trad. de Angela Corrêa et al. São Paulo: Contexto, 2008.

SCHMIDT, Sigfried J. Linguística e teoria de texto. São Paulo: Pioneira, 1978. 